\title{
Apoplastic Antioxidant Enzymes in the Leaves of Two Strawberry Cultivars and Their Relationship to Cold-Hardiness
}

\author{
Ece TURHAN ${ }^{1 *}$, Cigdem AYDOGAN ${ }^{1}$, Ali BAYKUL ${ }^{2}$, Anil \\ AKOGLU², Yasemin EVRENOSOGLU'2, Sergul ERGIN³ \\ ${ }^{1}$ Eskisehir Osmangazi University, Faculty of Agriculture, Department of Agricultural Biotechnology, \\ 26160, Eskisehir,Turkey; eturhan@ogu.edu.tr ( ${ }^{*}$ corresponding author) \\ ${ }^{2}$ Eskisehir Osmangazi University, Faculty of Agriculture, Department of Horticulture, 26160, Eskisehir, Turkey \\ ${ }^{3}$ Uludag University, Faculty of Agriculture, Department of Horticulture, 16059, Gorukle, Bursa, Turkey
}

\begin{abstract}
In this study, apoplastic antioxidant enzymes in the leaves of two strawberry cultivars ('Aromas' and 'Diamante') and their relationship to cold-hardiness were investigated. Fully expanded, uniformly sized leaves from 1-year-old field plants of the cultivars were collected at the hardening (late autumn, in November and winter, in January) and de-hardening (summer, in July) stages. Leaf samples were exposed to low temperatures of $5,-5,-10,-20$ and $-30^{\circ} \mathrm{C}$ for $12 \mathrm{~h}$ to determine their cold-hardiness $\left(\mathrm{LT}_{50}\right.$; lethal temperature, where $50 \%$ of the plants were killed). Cold-acclimation produced a remarkable increase in cold-hardiness. It was found that 'Diamante' had higher coldhardiness than 'Aromas'. Moreover, malondialdehyde and total carotenoid content increased during the hardening stage and decreased during the de-hardening stage. The activities of catalase, peroxidase and ascorbate peroxidase in the leaf apoplast and nicotinamide adenine dinucleotide phosphate oxidase activity in the leaf tissue were correlated with changes in cold-hardiness. The activities of these enzymes were higher in the hardening stage than in the de-hardening stage. The activities of apoplastic catalase, peroxidase and ascorbate peroxidase varied significantly depending on the cold-acclimation stage and the cold-hardiness level of the cultivars. This study indicates that elevated apoplastic antioxidative enzymes may be determinants of cold-hardiness in the strawberry plant. The lower malondialdehyde content and higher total carotenoid and apoplastic enzyme activities in 'Diamante' indicated an enhanced cold-hardiness capacity of this cultivar, serving to protect the plant from oxidative damage.
\end{abstract}

Keywords: antioxidative enzymes, apoplast, cold-hardiness, Fragaria $\times$ ananassa, oxidative stress, strawberry

Abbreviation: APX=Ascorbate peroxidase; CAT=Catalase; DMSO=Dimethyl sulphoxide; EDTA=Ethylenediamine-tetraacetic acid $\mathrm{GR}=$ Glutathione reductase; $\mathrm{H}_{2} \mathrm{O}_{2}=$ Hydrogen peroxide; IWF=Intercellular washing fluid; K-phosphate=Potassium phosphate; MDA=Malondialdehyde; $\mathrm{NAD}(\mathrm{P}) \mathrm{H}=$ Nicotinamide adenine dinucleotide phosphate; $\mathrm{O}_{2}=$ Superoxide; $\mathrm{O}_{2}{ }^{1}=$ Singlet oxygen; $\mathrm{OH}=$ Hydroxyl; POX=Peroxidase; PVPP=Polyvinylpolypyrrolidone; ROS=Reactive oxygen species; SOD=Superoxide dismutase; $\mathrm{TBA}=$ Thiobarbituric acid; $\mathrm{TCA}=$ Trichloroacetic acid; $\mathrm{TMB}=3,3,5,5$ '-tetramethylbenzidine

\section{Introduction}

Cold temperatures limit the geographical locations where crop and horticultural plant species can be grown and periodically cause significant losses in plant productivity (Thomashow and Browse, 1999). The process whereby certain plants increase in freezing tolerance in response to low nonfreezing temperatures is known as cold-acclimation (or cold-hardiness) (Levitt, 1980; Thomashow, 2010). In temperate latitudes, cold-acclimation is established in the autumn, when the temperatures are low but positive and the photoperiod decreases, and it reaches a maximum in winter (Reulland et al., 2009). Strawberry is a semihardy evergreen and has a relatively low tolerance to cold temperatures (Palonen and Buszard, 1997 a). Coldacclimation in strawberries begins when the days become shorter in late summer. Short days alone will trigger strawberries to develop tolerance to $-2^{\circ} \mathrm{C}$ or $-3^{\circ} \mathrm{C}$. For further acclimation, plants must be subjected to cold temperatures, i.e., days of approximately $10{ }^{\circ} \mathrm{C}$ and nights of approximately $0^{\circ} \mathrm{C}$ (Fisher, 2004).

The apoplast is the first plant compartment to encounter environmental signals (Gao et al., 2004). The apoplast consists of extracellular, aqueous spaces outside the plasma membrane, including cell walls, spaces between the cells and xylem (Sakurai, 1998). As temperatures drop below freezing, ice forms primarily in the intercellular spaces (Levitt, 1980). Injury to the tissue may result from ice formation, either within the symplast or via ice growth into the symplast (Gusta et al., 2004).

Plants respond to low temperature with a number of physiological, biochemical and developmental changes 
(Shinozaki and Yamaguchi-Shinozaki, 2000). One of the biochemical changes occurring when plants are subjected to low-temperature stress is the production of reactive oxygen species (ROS), such as the superoxide $\left(\mathrm{O}_{2}{ }^{-}\right)$, hydrogen peroxide $\left(\mathrm{H}_{2} \mathrm{O}_{2}\right)$, hydroxyl $(-\mathrm{OH})$ radicals and singlet oxygen $\left(\mathrm{O}_{2}{ }^{1}\right)$ (Foyer and Noctor, 2005; Karpinski et al., 2002; Suzuki and Mittler, 2006). ROS can severely disrupt normal metabolism through oxidative damage to lipids, protein and nucleic acids (Rout and Shaw, 2001). Plants contain complements of enzymatic and non-enzymatic antioxidants that play a role in regulating the levels of ROS. Antioxidative enzymes, such as superoxide dismutase (SOD: EC 1.15.1.1), catalase (CAT: EC 1.11.1.6), peroxidase (POX: EC 1.11.1.7), ascorbate peroxidase (APX: EC 1.11.1.11), and glutathione reductase (GR: EC 1.6.4.2), are the most important components in the scavenging system for ROS (Mc Kersie and Leshem, 1994; Noctor and Foyer, 1998). In addition, the antioxidant enzymes in the apoplastic spaces of plants under environmental stresses have been shown to play an important role in the regulation of the stress response (Mutlu et al., 2009; Taşgın et al., 2006). Non-enzymatic antioxidants, such as ascorbic acid, glutathione, flavonoids, carotenoids and tocopherols, also work in concert to control the cascades of uncontrolled oxidation and to protect plant cells from oxidative damage through the scavenging of ROS (Gill and Tuteja, 2010). Recent studies have shown that ROS could also play a key role in mediating important signal transduction events (Suzuki and Mittler, 2006). Thus, $\mathrm{ROS}$, such as $\mathrm{O}_{2}$, are produced by nicotinamide adenine dinucleotide phosphate oxidase $[\mathrm{NAD}(\mathrm{P}) \mathrm{H}$ oxidases: EC 1.6.3.1] during abiotic stress to activate stress-response pathways and induce defense mechanisms (Suzuki and Mittler, 2006).

Strawberry exposed to low temperature can increase cold resistance through an increase in the activity of antioxidative enzymes (Gülen et al., 2008; Zhang et al., 2008). In addition, acid invertase and sucrose synthase enzymes in the apoplast are regulated by cold-acclimation and deacclimation in strawberry plants (Turhan, 2012). There is, however, no information available on the apoplastic enzymes involved in antioxidative metabolism in strawberry during cold-acclimation. The aim of the present study was to investigate changes in lipid peroxidation, total carotenoid content, NAD $(\mathrm{P}) \mathrm{H}$ oxidase activity and apoplastic antioxidative enzyme (CAT, POX and APX) activities under hardening and de-hardening stages in 'Aromas' and 'Diamante' strawberry cultivars with contrasting levels of cold-hardiness.

\section{Materials and methods}

\section{Plant material}

Uniformly sized plants of approximately 1-year-old 'Aromas' and 'Diamante' cultivars were used. Both cultivars are day-neutral and were originally licensed by the University of California. The two cultivars are adapted to different temperature zones. Although 'Aromas' has broader environmental tolerance than 'Diamante' (Anonymous, 2012), it has been found that 'Diamante' is relatively more tolerant to low temperature than 'Aromas' (Turhan et al., 2011). Fully expanded, uniformly sized leaves from introduced strawberry cultivars were collected from plants in Eskisehir, Turkey $\left(39^{\circ} 47^{\prime} \mathrm{N}, 30^{\circ} 31^{\prime} \mathrm{E}\right)$ in summer (in July), late autumn (in November) and winter (in January). The monthly mean, maximum and minimum temperatures in the experimental area are shown in Fig. 1. Leaf samples were collected randomly from twenty plants of each cultivar, packed on ice and taken to the laboratory. Parts of the leaves from each treatment group were then processed to determine cold-hardiness. Fresh tissue was also used immediately for all malondialdehyde (MDA) and total carotenoid determination assays and for the preparation of intercellular washing fluid (IWF).

\section{Controlled freezing test}

Leaves from each cultivar were wrapped (10 leaves per temperature in each replication) in aluminum foil along with moistened paper and placed in a manually controlled low-temperature freezer. The plant tissue temperature was monitored with a copper-constant thermocouple (Testo 925, Omni Inst., Scotland, UK) inserted in the foil pouch. The temperature was decreased stepwise at approximately $1.5^{\circ} \mathrm{C} / \mathrm{h}$ to $-5^{\circ} \mathrm{C}$ and $5^{\circ} \mathrm{C} / \mathrm{h}$ thereafter to a final value of $-30^{\circ} \mathrm{C}$. The samples were exposed to low temperatures of $5,-5,-10,-20$ or $-30^{\circ} \mathrm{C}$ for $12 \mathrm{~h}$. The samples were then removed from the freezer at each temperature and placed at $4^{\circ} \mathrm{C}$ overnight for slow thawing.

\section{Cold-hardiness determination}

At each temperature, the cold-hardiness of the leaf tissues was estimated by assaying freezing injury using the electrolyte leakage method of Arora et al. (1992). Briefly, leaf discs ( $10 \mathrm{~mm}$ diameter) were cut from the leaves; they were then lightly rinsed in distilled water, gently blotted with paper and placed in test tubes (one disc per tube). Distilled water $(10 \mathrm{~mL})$ was added to the test tubes, which were then vacuum-infiltrated to allow uniform diffusion of the electrolytes. The tubes were shaken on an orbital shaker (250 rpm) (Unimax 2010, Heidolph Instruments, Germany) for $4 \mathrm{~h}$ at room temperature. The electrical con-

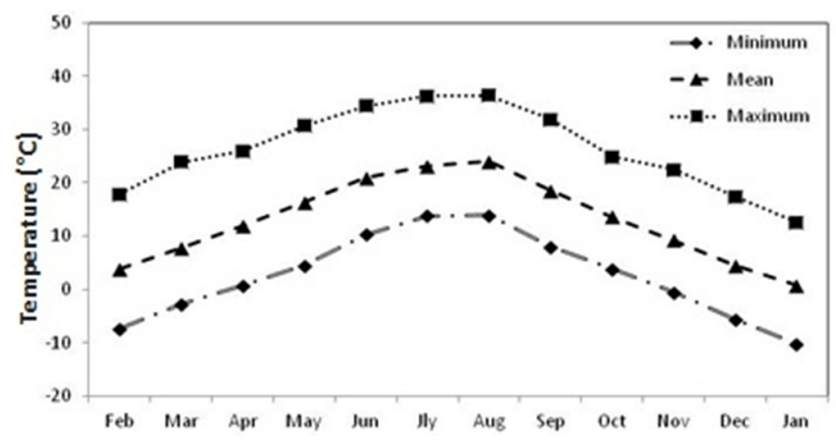

Fig. 1. Monthly mean, maximum and minimum temperatures at the experimental site (from February 2009 to January 2010) 
116

ductivity of each sample was measured using a conductivity meter (YSI 3200, USA). Electrical conductivity was measured once more after the tubes were autoclaved $(0.12$ $\mathrm{MPa}, 120^{\circ} \mathrm{C}, 20 \mathrm{~min}$ ) and cooled. Proportional injury at each temperature was calculated from ion leakage data with the following equation:

Proportional injury $=[($ proportional $\mathrm{L}(\mathrm{t})$-proportional L(c))/(100-proportional L(c))]*100

where proportional $\mathrm{L}_{(\mathrm{c})}$ and proportional $\mathrm{L}_{(\mathrm{c})}$ are the proportional ion leakage data for the treatments and control samples, respectively (Arora et al., 1992). In addition, the survival of the plants was determined for $\mathrm{LT}_{50}$ estimation (lethal temperature, where $50 \%$ of the plants were killed). The $\mathrm{LT}_{50}$ was defined as the temperature causing half-maximal \% injury, calculated as the midpoint between the maximum injury and the control.

\section{Preparation of intercellular washing fuid (IWF)}

Apoplastic IWF was extracted from leaf tissues according to Fecht-Christoffers et al. (2003). Freshly harvested leaves were cut into small pieces (approximately $5 \mathrm{~mm}$ in width) and rinsed for 2 min with tap water. Leaves (approximately $10 \mathrm{~g}$ ) were immersed in distilled water for $1 \mathrm{~min}$, then vacuum infiltrated for 5 min under a weak vacuum $(-40 \mathrm{kPa})$ (KNF Neuberger, Germany). The infiltrated tissue was then gently surface-dried and centrifuged at room temperature for $1 \mathrm{~min}$ at $1,200 \times g$. The resulting fluid (apoplast) was collected and dispensed equally (200 $\mu \mathrm{L}$ ) to Eppendorf tubes, placed in liquid $\mathrm{N}_{2}$ and kept at $-80^{\circ} \mathrm{C}$ prior to further analyses.

\section{Lipid peroxidation}

Lipid peroxidation was estimated by determining the malondialdehyde (MDA) content in the leaves according to the method of Rajinder $e$ al al. (1981). One hundred milligrams of fresh leaf samples was homogenized in 5 $\mathrm{mL}$ of $0.1 \%$ trichloroacetic acid (TCA). The homogenate was centrifuged at $10,000 \times g$ for $5 \mathrm{~min}$ at $4^{\circ} \mathrm{C}(\mathrm{Beckman}$ Coulter Allegra 64R, USA). An aliquot of $0.3 \mathrm{~mL}$ of supernatant was mixed with $1.2 \mathrm{~mL}$ of $0.5 \%$ thiobarbituric acid (TBA) prepared in $20 \%$ TCA and incubated at $95^{\circ} \mathrm{C}$ for $30 \mathrm{~min}$. After stopping the reaction in an ice bath for $5 \mathrm{~min}$, the samples were centrifuged at $10,000 \times g$ for 10 $\min$ at $25^{\circ} \mathrm{C}$ The supernatant absorbance at $532 \mathrm{~nm}$ was then measured with a spectrophotometer (Perkin Elmer Lambda 25, USA). After subtracting the non-specific absorbance at $600 \mathrm{~nm}$, the MDA concentration was determined using an extinction coefficient of $155 \mathrm{mM}^{-1} \mathrm{~cm}^{-1}$.

\section{Total carotenoid content}

The total carotenoid content was quantified according to Lichtenthaler and Wellburn (1983), with some modifications. Fresh leaf tissues were homogenized in ice with a homogenizer (Miccra D-1, Germany). Extracts were shaken at $120 \mathrm{rpm}$ for three hours in the dark. Fifteen minutes later, the absorbance of the extract at $460 \mathrm{~nm}$ was mea- sured with a spectrophotometer (Perkin Elmer Lambda 25, USA).

\section{$N A D(P) H$ oxidase activity assay}

$\mathrm{NAD}(\mathrm{P}) \mathrm{H}$ oxidase was extracted with a mortar and pestle from $1.0 \mathrm{~g}$ of leaf tissue at $4^{\circ} \mathrm{C}$ with $1.0 \%$ polyvinylpolypyrrolidone (PVPP) and $5 \mathrm{~mL}$ of the following extraction solution: $100 \mathrm{mM}$ Potassium phosphate (Kphosphate) buffer at $\mathrm{pH} 7.0,0.1 \mathrm{mM}$ ethylenediaminetetraacetic acid (EDTA), and $0.1 \%$ Triton. The extract was centrifuged at 15,000 $\times g$ for 20 min (Beckman Coulter Allegra 64R, USA). The supernatant was used for the enzymatic assay. $\mathrm{NAD}(\mathrm{P}) \mathrm{H}$ oxidase was assayed according to Cakmak and Marschner (1988). The reaction mixture (1.5 $\mathrm{mL}$ ) contained $0.1 \mathrm{M} \mathrm{K}$-phosphate buffer, $\mathrm{pH} 7.0,0.1 \mathrm{mM}$ EDTA and $50 \mathrm{mM}$ NADPH or NADH. The reaction was initiated by adding $200 \mu \mathrm{L}$ of the enzyme extract, and the oxidation of NADPH or NADH was recorded with a spectrophotometer at $340 \mathrm{~nm}$. The total soluble protein content of the crude enzyme extracts was determined with the Bradford assay method (Bradford, 1976).

\section{Determination of apoplastic enzyme activity}

The activities of CAT, POX and APX in the apoplastic fractions were determined spectrophotometrically. CAT was assayed by monitoring the consumption of $\mathrm{H}_{2} \mathrm{O}_{2}$ in a spectrophotometer (Perkin Elmer Lambda 25, USA) at $240 \mathrm{~nm}$ (Rao et al., 1996). The activity was calculated using an extinction coefficient of $39.4 \mathrm{mM} / \mathrm{cm}$ for $\mathrm{H}_{2} \mathrm{O}_{2}$. Apoplastic peroxidase activity was measured according to Andrews et al. (2000). Aliquots of $100 \mu \mathrm{L}$ IWF were added to $2 \mathrm{~mL}$ reaction mixtures containing $100 \mathrm{mM} \mathrm{Na}$ -

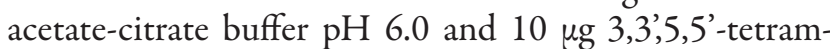
ethylbenzidine (TMB), solubilized initially in dimethyl sulfoxide (DMSO). The reaction was initiated by adding $10 \mu \mathrm{L} 6 \% \mathrm{H}_{2} \mathrm{O}_{2}$, and incubation was performed for 30 min at $25^{\circ} \mathrm{C}$. To stop the reaction, $0.5 \mathrm{~mL} 0.6 \mathrm{M} \mathrm{H}_{2} \mathrm{SO}_{4}$ was added, and the optical density of the yellow color was determined at $450 \mathrm{~nm}$ with a UV/VIS spectrophotometer (Perkin Elmer Lambda 25, USA). Enzyme activity was expressed relative to a standard curve obtained with horseradish peroxidase (Sigma Chemical Co. Ltd.). APX activity was determined by measuring the decrease in absorbance of the oxidized ascorbate at $290 \mathrm{~nm}$, according to Nakano and Asada (1980). The concentration of oxidized ascorbate was calculated with the extinction coefficient $£=2.8 \mathrm{mM} / \mathrm{cm}$; one unit of APX was defined as $1 \mu \mathrm{mol} /$ $\mathrm{mL}$ ascorbate oxidized per minute.

\section{Statistical analysis}

The experiment was arranged in a randomized block design with three replications. The data were tested with SPSS 13.0 for Windows (SPSS Inc., Chicago, IL, USA). Differences between means were evaluated with a Duncan test at $p<0.05$. 


\section{Results and discussion}

\section{Cold-hardiness}

Cold-hardiness, expressed as the $\mathrm{LT}_{50}$ of leaf tissue from two strawberry cultivars, is shown in Fig. 2. The coldhardiness of the cultivars increased in the hardening stages (late autumn: average $\mathrm{LT}_{50}-18.9^{\circ} \mathrm{C}$; winter: average $\mathrm{LT}_{50}$ $-23.4^{\circ} \mathrm{C}$ ) and decreased in the de-hardening stage (summer: average $\mathrm{LT}_{50}-13 \cdot 2^{\circ} \mathrm{C}$ ). Cold-acclimation produced an increase in the freezing tolerance of the cultivars (by lowering $\left.\mathrm{LT}_{50}\right)$. The greatest increase was observed in 'Diamante' $\left(-19.5^{\circ} \mathrm{C}\right)$. In contrast, 'Aromas' had the lowest cold-hardiness $\left(-17 \cdot 6^{\circ} \mathrm{C}\right)$. A two-way ANOVA revealed significant effects of sampling stage and cultivar on coldhardiness but no significant interaction between sampling stage and cultivar $\left(\mathrm{LT}_{50} ;\right.$ Tab. 1).

Winter cold-hardiness is an important component of cultivars developed for colder climates. In our study, a clear increase in cold-hardiness was observed in the leaf tissues of 'Aromas' and 'Diamante' strawberry cultivars in response to decreasing temperature during the late autumn and winter (Fig. 2). Increases in cold-hardiness were reported during cold-acclimation in strawberry (Marini and Boyce, 1977; Palonen and Lindén, 2002; Paquin et al., 1989), as well as in many other plant species such as wheat (Apostolova et al., 2008), peach (Arora et al., 1992) and olive (Cansev et al., 2009; Eris et al., 2007). Palonen and Buszard (1997 b) stated that cultivar differences in coldhardiness are only revealed after acclimation. The results of the current study showed that 'Diamante' had higher cold-

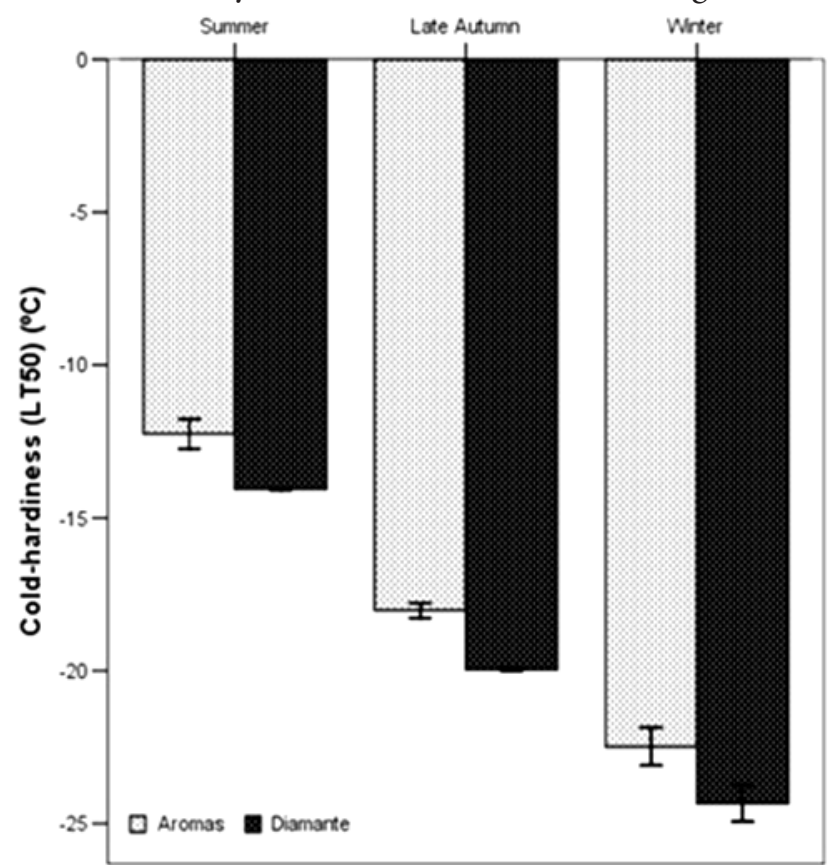

Fig. 2. Cold-hardiness $\left(\mathrm{LT}_{50}\right)$ of two strawberry cultivars in hardening (late autumn, November and winter, January) and de-hardening (summer, in July) leaf tissues. $\mathrm{LT}_{50}$ was assessed by electrolyte leakage. Error bars represent \pm SE of three replications
Tab. 1. Results of analysis of variance (ANOVA) of stage (S), cultivar (Cv.), and their interactions with cold-hardiness $\left(\mathrm{LT}_{50}\right)$, malondialdehyde (MDA) content, total carotenoid content and $\mathrm{NAD}(\mathrm{P}) \mathrm{H}$ oxidase activity in leaf tissues and with catalase (CAT), peroxidase (POX) and ascorbate peroxidase (APX) activity in leaf apoplast. Numbers represent $F$ values relative to a significance level of 0.05

\begin{tabular}{cccc}
\hline \multirow{2}{*}{ Dependent variable } & \multicolumn{3}{c}{ Independent variable } \\
\cline { 2 - 4 } & $\mathrm{S}$ & $\mathrm{Cv}$. & $\mathrm{SxCv}_{\mathrm{x}}$ \\
\hline $\mathrm{LT}_{50}$ & $263.807^{*}$ & $22.362^{*}$ & 0.008 \\
MDA content & $80.063^{*}$ & $13.213^{*}$ & 4.140 \\
Total carotenoid content & $9.783^{*}$ & $10.113^{*}$ & 0.108 \\
NAD $(\mathrm{P}) \mathrm{H}$ oxidase activity & $147.255^{*}$ & 0.406 & 0.205 \\
Apoplastic CAT activity & $530.287^{*}$ & $510.433^{*}$ & $32.333^{*}$ \\
Apoplastic POX activity & $310.439^{*}$ & $20.417^{*}$ & 1.425 \\
Apoplastic APX activity & $40.926^{*}$ & $25.788^{*}$ & 4.181 \\
\hline
\end{tabular}

${ }^{*}$ Significant at $p<0.05$

hardiness than 'Aromas'. In addition, Turhan et al. (2011) recently investigated the occurrence of cell membrane injury in these cultivars in response to low temperatures. 'Diamante' was found to be relatively more tolerant to low temperatures than 'Aromas.

\section{Lipid peroxidation}

The changes in MDA content in the leaf tissues are shown in Fig. 3. MDA content increased during the hardening stages (during late autumn and winter) and decreased during the de-hardening stage (summer). According to the average values, the maximum MDA content occurred in winter $\left(195.2 \mathrm{nmol} \mathrm{g}^{-1} \mathrm{FW}\right)$ and late autumn $(165.2 \mathrm{nmol}$

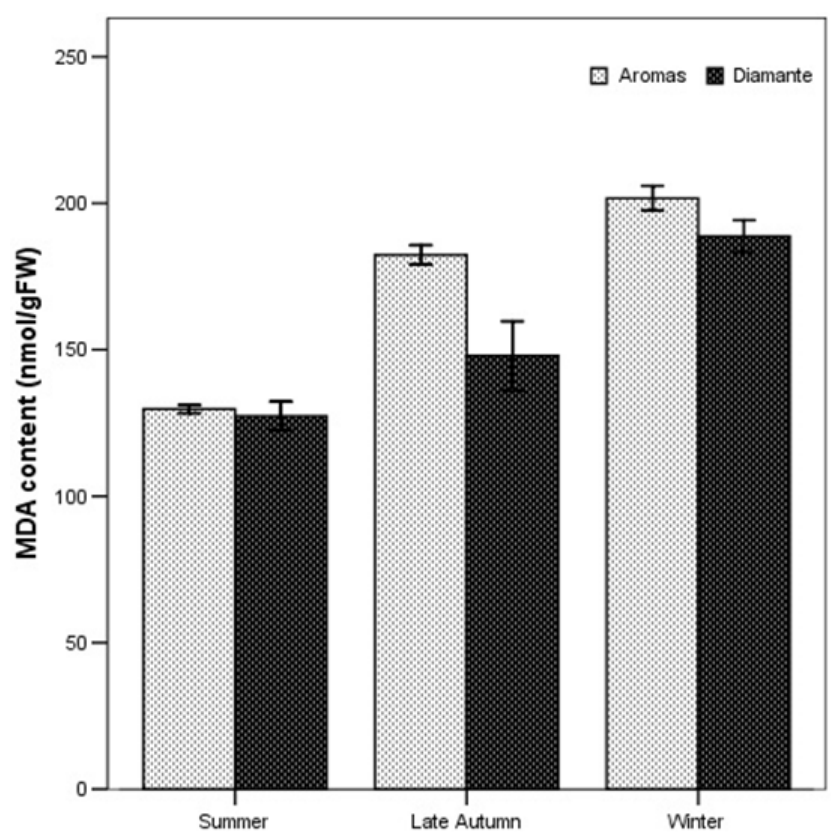

Fig. 3. Malondialdehyde (MDA) content in the hardening (in late autumn and winter) and de-hardening (in summer) leaf tissues of two strawberry cultivars. Error bars represent \pm SE of three replications 
118

$\left.\mathrm{g}^{-1} \mathrm{FW}\right)$, whereas the minimum MDA content occurred in summer (128.6 nmol g-1 FW). MDA content was higher in 'Aromas' than in 'Diamante' during both the hardening and the de-hardening stages. A two-way ANOVA revealed a significant effect of sampling stage and cultivar on MDA content in the leaf tissues but no significant interaction between sampling stage and cultivar (Tab. 1).

Membrane lipid peroxidation results from a malfunction of the scavenging system and can cause damage to the major cellular components (Monk et al., 1989). The accumulation of MDA is often used as an indicator of lipid peroxidation (Smirnoff, 1995). Cold exposure produced increased MDA content both in 'Aromas' and 'Diamante' (Fig. 3). This result indicated that the accumulation of ROS caused membrane damage. Besides, this result is consistent with previous findings in strawberry (Gülen et al., 2008; Luo et al., 2011) and Arabidopsis (Xue et al., 2009). In addition, 'Aromas', which showed lower cold-hardiness than 'Diamante', had a higher MDA content in all sampling periods.

\section{Total carotenoid content}

Two cultivars had a significantly higher total carotenoid content in the leaf tissues in the hardening stages than in the de-hardening stages (Fig. 4). The data from the three sampling stages showed that the total carotenoid content of 'Diamante' $(0.024 \mathrm{mg} / \mathrm{g}$ FW; Fig. 4) was greater than that of 'Aromas' (0.022 mg/g FW; Fig. 4). A twoway ANOVA found a significant effect of sampling stage and cultivar on total carotenoid content but no significant interaction between sampling stage and cultivar (Tab. 1).

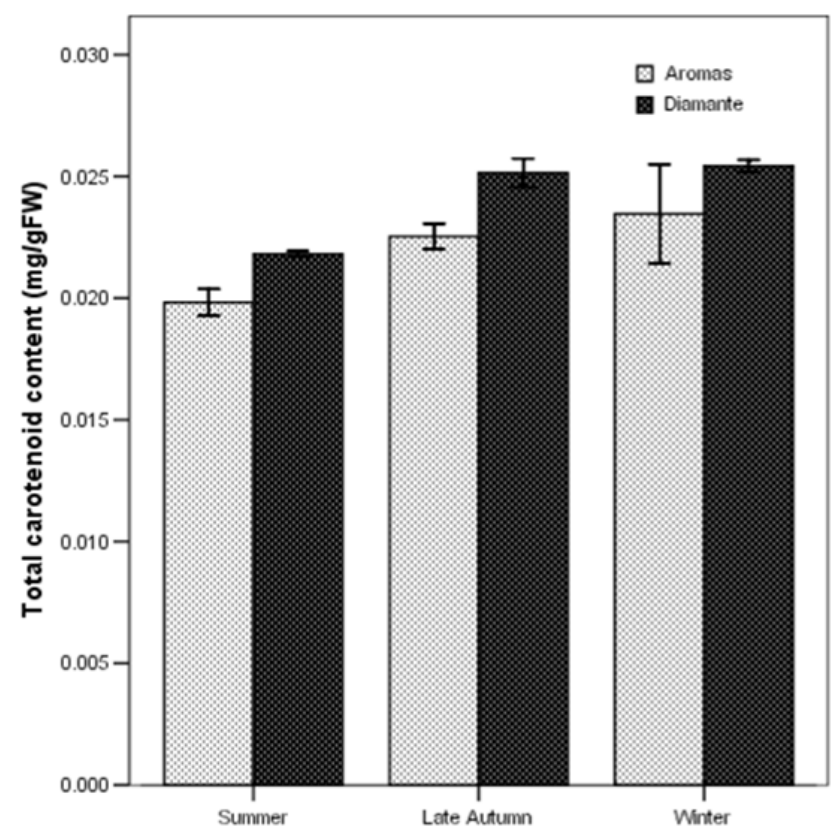

Fig. 4. Total carotenoid content in the hardening (in late autumn and winter) and de-hardening (in summer) leaf tissues of two strawberry cultivars. Error bars represent \pm SE of three replications
Carotenoid is a lipid-soluble antioxidant that plays a multitude of roles in plant metabolism, including that of oxidative stress tolerance (Gill and Tuteja, 2010). Similarly, Turan and Ekmekci (2011) found that chilling temperatures produced a gradual increase in carotenoid content in 'Canitez 87' and 'Gökçe' chickpea cultivars. However, the same author remarked that this increase was more significant in the 'Canitez 87' cultivar, which is more sensitive to chilling temperatures.

\section{$N A D(P) H$ oxidase activity}

In general, the average $\mathrm{NAD}(\mathrm{P}) \mathrm{H}$ oxidase activity in the hardening stage (during late autumn: $176.6 \mathrm{nmol} / \mathrm{mg}$ protein/min; winter: $232.8 \mathrm{nmol} / \mathrm{mg}$ protein/min, Fig. 5) was significantly higher than that in the de-hardening stage (summer: $88.6 \mathrm{nmol} / \mathrm{mg}$ protein $/ \mathrm{min}$, Fig. 5). NAD(P)H oxidase activity in summer and in winter was higher in $\mathrm{cv}$. 'Diamante' than in cv. 'Aromas'. Based on the average values of data from the three stages, 'Diamante' (168.2 nmol/ $\mathrm{mg}$ protein/min) had higher $\mathrm{NAD}(\mathrm{P}) \mathrm{H}$ oxidase activities than 'Aromas' (163.8 $\mathrm{nmol} / \mathrm{mg}$ protein/min). A two-way ANOVA revealed a significant effect of sampling stage on $\mathrm{NAD}(\mathrm{P}) \mathrm{H}$ oxidase activity but no significant effect of the cultivar or of the interaction between sampling stage and cultivar (Tab. 1).

$\mathrm{NAD}(\mathrm{P}) \mathrm{H}$ oxidase homologs have been implicated as key players in the production of $\mathrm{O}_{2}{ }^{-}$in plants (Mittler et al., 2004). $\mathrm{NAD}(\mathrm{P}) \mathrm{H}$ oxidase is also activated during abiotic stress to generate ROS that are used as signal transduction molecules (Mittler et al., 2004). In the current study, the activity of $\mathrm{NAD}(\mathrm{P}) \mathrm{H}$ oxidase was investigated to examine the association of ROS formation with coldhardiness. It was found that $\mathrm{NAD}(\mathrm{P}) \mathrm{H}$ oxidase activity was significantly higher in the hardening stage than in the de-hardening stage in leaves of the two strawberry cultivars (Fig. 5). These data strongly suggest that during coldacclimation, the activation of $\mathrm{NAD}(\mathrm{P}) \mathrm{H}$ oxidase, which triggers superoxide radicals, was directly correlated with the degree of tolerance to cold. Similarly, it was reported that changes in $\mathrm{NAD}(\mathrm{P}) \mathrm{H}$ oxidase activity were related to variation in the freezing tolerance of olive (Cansev et al., 2009). However, NAD(P)H oxidase activity may not be involved in determining cultivar sensitivity to cold stress in strawberry because no significant difference was found between the cultivars.

\section{Apoplastic enzyme activity}

The changes of CAT activity in the apoplast of leaf tissues are shown in Fig. 6A. In general, the average CAT activity in the hardening stage (during winter: $52.4 \mathrm{nmol} /$ $\mathrm{mL}$ IWF, during late autumn: $33.9 \mathrm{nmol} / \mathrm{mL}$ IWF) was significantly higher than that in the de-hardening stage (summer: $19.2 \mathrm{nmol} / \mathrm{mL}$ IWF). CAT enzyme activity was higher in the leaf apoplast of 'Diamante' than in 'Aromas' in all sampling stages. A two-way ANOVA revealed significant effects of sampling stage, cultivar and the interac- 
tion between sampling stage and cultivar on CAT activity (Tab. 1).

In plant cells subjected to stresses, the initial events occur primarily in the apoplastic space (Atic1 and Nalbantoglu 2003, Taşgin et al. 2003, 2006). In plants, $\mathrm{H}_{2} \mathrm{O}_{2}$ is destroyed primarily by APX and catalases (Asada, 1992). Although the catalases are restricted to the peroxisomes and perhaps to the mitochondria (Asada, 1992; Jime'nez et al., 1997), CAT activity was also found in the apoplastic region of barley (Vanacker et al., 1998), tomato (Patykowski and Urbanek, 2003) and wheat leaves (Çakmak and Atıc1, 2009; Mutlu et al., 2009). The significant increase in CAT activity during the hardening stages in both strawberry cultivars (Fig. 6A) observed in this study may be a result of the greater tolerance of the cultivars to cold conditions. This result suggests that CAT activation is directly correlated with the degree of cold-hardiness in strawberry plants. In addition, 'Diamante', which showed greater cold-hardiness in the present study, exhibited greater apoplastic CAT activity than did 'Aromas'. The association of apoplastic CAT with cold tolerance found by the present study is in good agreement with several previous studies that have demonstrated the important role of apoplastic CAT in increasing oxidative tolerance in plant tissues (Çakmak and Atıcı, 2009; Mutlu et al., 2009; Patykowski and Urbanek, 2003).

POX activity in the apoplast of leaf tissues in the sampling stages is shown in Fig. 6B. Apoplastic POX activity of both strawberry cultivars was significantly higher in winter $(0.25$ units $/ \mathrm{mL}$ IWF) than in late autumn $(0.12$

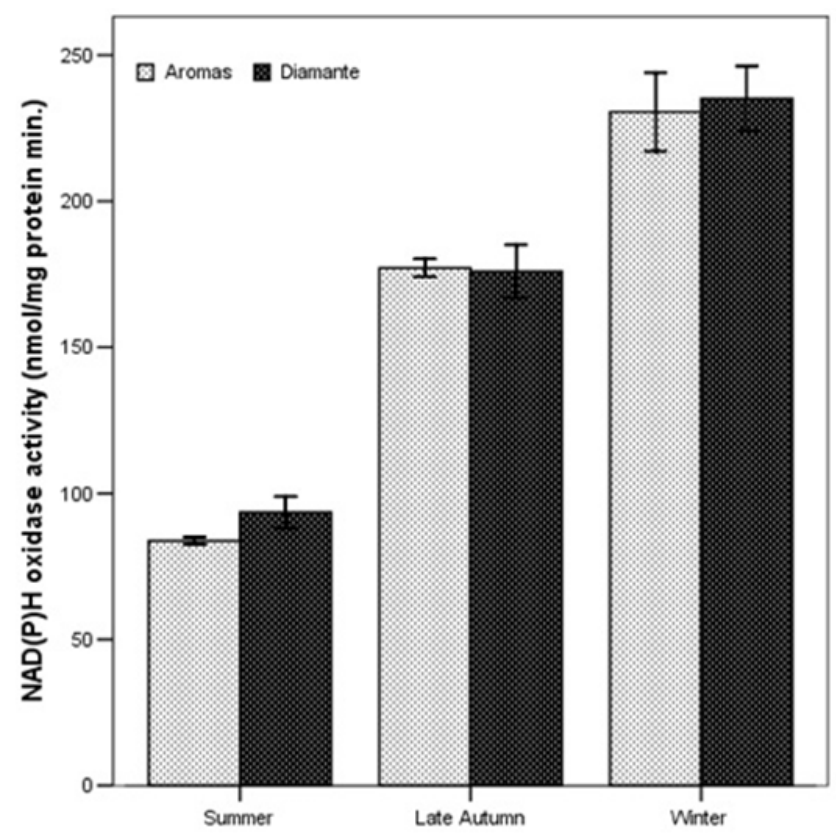

Fig. 5. $\mathrm{NAD}(\mathrm{P}) \mathrm{H}$ oxidase activity in the hardening (in late autumn and winter) and de-hardening (in summer) leaf tissues of two strawberry cultivars. Error bars represent \pm SE of three replications
units/mL IWF) and summer (0.11 units/mL IWF). Apoplastic POX activity was higher in cv. 'Diamante' than in cv. 'Aromas' at all sampling stages. A two-way ANOVA found significant effects of sampling stage and cultivar on POX enzyme activity in the apoplast of leaf tissues but no significant interaction between sampling stage and culti$\operatorname{var}$ (Tab. 1).

The most common biosynthetic pathway in the apoplast is lignin biosynthesis. In this pathway, phenylpropanoid precursors of lignin are cross-linked by $\mathrm{H}_{2} \mathrm{O}_{2}$ in reactions initiated by peroxidases (Gross, 1980). In our study, 'Diamante', with a high level of cold-hardiness, had significantly higher apoplastic POX activity than 'Aromas', with a low level of cold-hardiness, in both the hardening and the de-hardening stages (Fig. 6B). Thus, a higher apoplastic POX activity was associated with greater cold-hardiness of the cultivars. This POX activation profile is in good agreement with the data for apoplastic POX enzyme activity in winter wheat leaves (Çakmak and Atıc1, 2009). However, a significant increase in the activity of this enzyme occurred during the hardening stage. This result suggests that this increase in enzyme activity may be related to cold-acclimation. POX activity in the leaf apoplast increased during the hardening stage in both cultivars. Several previous reports have suggested that apoplastic peroxidase is involved in crosslinking cell-wall components (Passardi et al., 2004), increasing cellular resistance to abiotic stresses.

The changes of APX activity in the apoplast of the leaf tissues are shown in Fig. 6C. APX activity increased during the hardening stage and decreased during the dehardening stage. Based on the average values, the maximum APX activity occurred in winter $(\sim 429.0 \mathrm{nmol} / \mathrm{mL}$ IWF) and late autumn $(\sim 429.0 \mathrm{nmol} / \mathrm{mL}$ IWF $)$, whereas the minimum APX activity occurred in summer (201.2 $\mathrm{nmol} / \mathrm{mL}$ IWF). Apoplastic APX activity was higher in 'Diamante' than in 'Aromas' at all sampling stages. A twoway ANOVA found a significant effect of sampling stage and cultivar on APX activity in the apoplast of leaf tissues but no significant interaction between sampling stage and cultivar (Tab. 1).

One of the principal $\mathrm{H}_{2} \mathrm{O}_{2}$-scavenging enzymes in leaves is APX, which is located in the chloroplast, cytosol and apoplast (Asada, 1992). It was found that APX activity in the apoplast of two strawberry cultivars was significantly higher in the hardening stage than in the de-hardening stage (Fig. 6C). In addition, apoplastic APX activity was higher in 'Diamante', which had greater cold-hardiness than 'Aromas' at all stages. This result is in good agreement with previous results on apoplastic APX enzyme activity relative to increasing oxidative tolerance in barley (Vanacker et al., 1998) and tomato (Patykowski and Urbanek, 2003). 
120
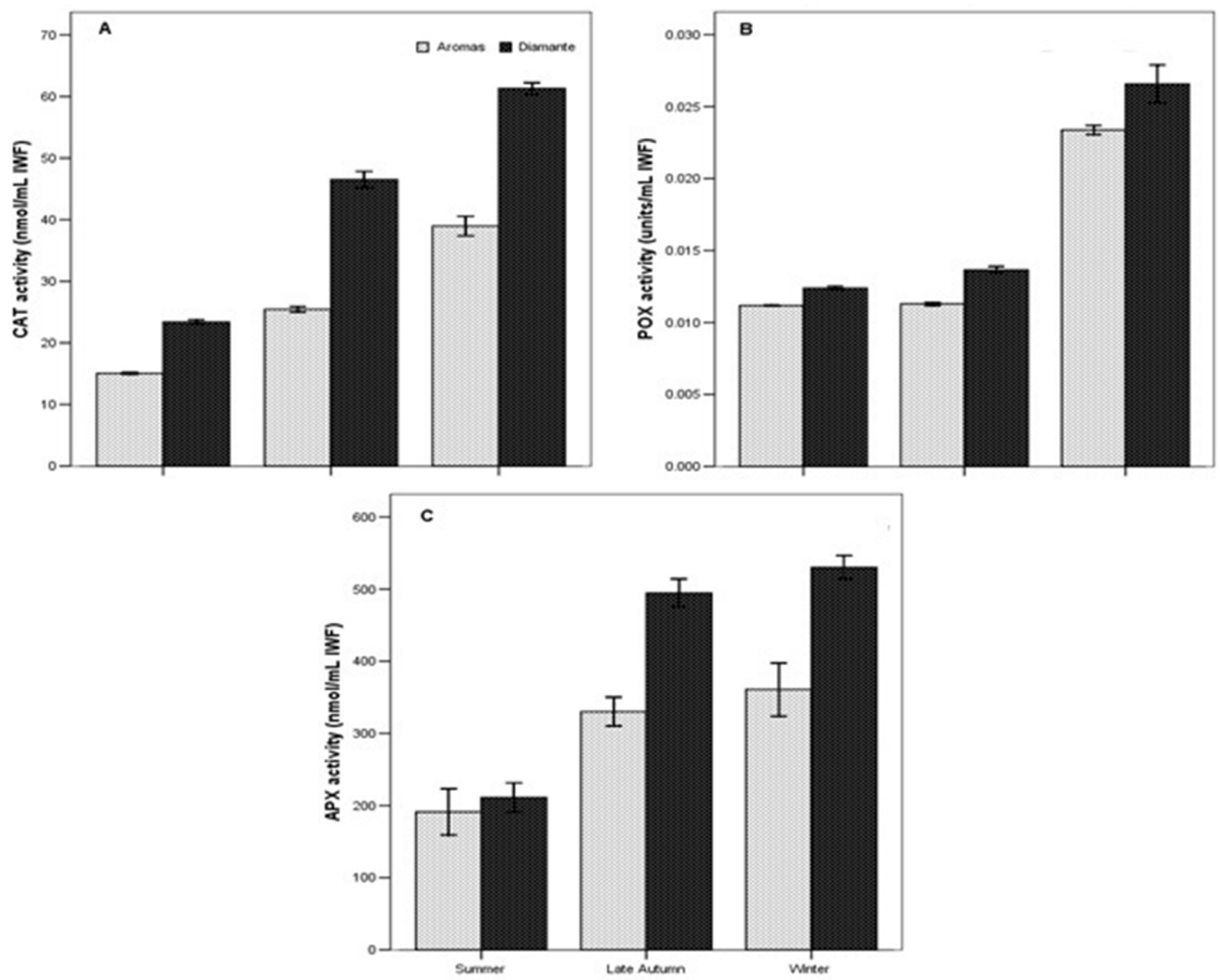

Fig. 6. Apoplastic catalase (CAT; A), peroxidase (POX; B), ascorbate peroxidase (APX; C) activities in the hardening (in late autumn and winter) and de-hardening (in summer) leaf tissues of two strawberry cultivars. Error bars represent \pm SE of three replications

\section{Conclusions}

The principal conclusion of this study is that a substantial difference in cold-hardiness was found between the cold-acclimated and non-acclimated stages of strawberry plants. In addition, various apoplastic antioxidative enzymes are associated with cold-acclimation or cold-hardiness in strawberry leaf tissues, and the two strawberry cultivars investigated showed different levels of cold-hardiness, most likely due to different antioxidant capacity.

CAT, POX and APX activity in the apoplast and $\mathrm{NAD}(\mathrm{P}) \mathrm{H}$ oxidase activity in leaf tissues during the hardening stages were associated with the $\mathrm{LT}_{50}$ values. Indeed, antioxidative enzymes such CAT, POX and APX were more effective in the relatively more tolerant 'Diamante' cultivar. To the best of our knowledge, this is the first report indicating that various apoplastic antioxidative enzymes are associated with cold-acclimation or cold-hardiness in strawberry leaf tissues on a cultivar basis. Nevertheless, it will be necessary to repeat the experiment with more cultivars to obtain precise information and further results.

\section{Acknowledgments}

The authors thank Ciltar A.S. (Adana, Turkey) for supplying the plant materials used in the study.

\section{References}

Andrews J, Malone M, Thompson DS, Ho LC, Burton KS (2000). Peroxidase isoenzyme patterns in the skin of maturing tomato fruits. Plant Cell Environ 23:415-422.

Anonymous (2012). Office of Research-University of California, Davis website. http://www.research.ucdavis.edu/strawberry/aro/aro

Apostolova P, Yordanova R, Popova L (2008). Response of antioxidative defence system to low temperature stress in two wheat cultivars. Gen Appl Plant Physiol Special Issue 34(34):281-294. 
Arora R, Wisniewski ME, Scorza R (1992). Cold acclimation in genetically related (sibling) deciduous and evergreen peach (Prunus persica [L.] Batsch) I: Seasonal changes in coldhardiness and polypeptides of bark and xylem tissues. Plant Physiol 99:1562-1568.

Asada K (1992). Ascorbate peroxidise-a hydrogen peroxide scavenging enzyme in plants. Physiol Plant 85:235-241.

Atıcı Ö, Nalbantoğlu B (2003). Antifreeze proteins in higher plants. Phytochemistry 64:1187-1196.

Bradford MM (1976). A rapid and sensitive method for quantitation of microgram quantities of protein utilizing the principle of protein-dye binding. Anal Biochem 72:248254.

Cakmak I, Marschner H (1988). Zinc-dependent changes in electron spin resonance signals, NADPH oxidase and plasma membrane permeability in cotton roots. Physiol Plant 73:182-186.

Cansev A, Gulen H, Eris A (2009). Cold-hardiness of olive (Olea europaea 1.) cultivars in cold-acclimated and non-acclimated stages: seasonal alteration of antioxidative enzymes and dehydrin-like proteins. J Agr Sci 147:51-61.

Çakmak T, Atıcı Ö (2009). Effects of putrescine and low temperature on the apoplastic antioxidant enzymes in the leaves of two wheat cultivars. Plant Soil Environ 55(8):320326.

Eris A, Gulen H, Barut E, Cansev A (2007). Annual patterns of total soluble sugars and proteins related to cold-hardiness in olive (Olea europaea L. 'Gemlik'). J Hortic Sci Biotech 82:597-604.

FisherP(2004).Coldacclimation instrawberries: Howstrawberry plants get ready for winter. http://www.omafra.gov.on.ca/ english/crops/hort/news/hortmatt/2004/28hrt04a6.htm.

Foyer CH, Noctor G (2005). Oxidant and antioxidant signaling in plants: a re-evaluation of the concept of oxidative stress in a physiological context. Plant Cell Environ 28:1056-1071.

Fecht-Christoffers MM, Maier P, Horst WJ (2003). Apoplastic peroxidases and ascorbate are involved in manganese toxicity and tolerance of Vigna unguiculata. Physiol Plant 117:237244.

Gao D, Knight MR, Trewavas AJ, Sattelmacher B, Plieth C (2004). Self-reporting Arabidopsis expressing pH and Ca2+ indicators unveil ion dynamics in the cytoplasm and in the apoplast under abiotic stress. Plant Physiol 134:898-908.

Gill SS, Tuteja N (2010). Reactive oxygen species and antioxidant machinery in abiotic stress tolerance in crop plants. Plant Physiol Bioch 48:909-930.

Gusta LV, Wisniewski M, Nesbitt NT, Gusta ML (2004). The effect of water, sugars, and proteins on the pattern of ice nucleation and propagation in acclimated and nonacclimated canola leaves. Plant Physiol 135:1642-1653.

Gülen H, Çetinkaya C, Kadığlu M, Kesici M, Cansev A, Eriş A (2008). Peroxidase activity and lipid peroxidation in strawberry (Fragaria $\times$ ananassa) plants under low temperature. J Biol Environ Sci 2:95-100.

Gross GG (1980). The biochemistry of lignification. Adv Bot Res 8:25-63.

Jime'nez A, Herna'ndez JA, de Rio LA, Sevilla F (1997). Evidence for the presence of the ascorbate-glutathione cycle in mitochondria and peroxisomes of pea leaves. Plant Physiol 114:275-284.

Karpinski S, Wingsle G, Karpinska B, Hallgren J (2002). Low temperature stress and antioxidant defense mechanisms in higher plants, 69-103 p. In: Inze D, Van Montagu M (Eds.). Oxidative Stress in Plants. Taylor \& Francis, London and New York.

Levitt J (1980). Responses of Plants to Environmental Stress. Chilling, Freezing, and High Temperature Stresses. 2nd ed. Academic Press, New York, 370 p.

Lichtenthaler HK, Wellburn AR (1983). Determinations of total carotenoids and chlorophylls a and b of leaf extracts in different solvents. Biochem Soc Trans 11:591-592.

Luo Y, Tang H, Zhang Y (2011). Production of reactive oxygen species and antioxidant metabolism about strawberry leaves to low temperature. Journal of Agricultural Science 3(2):8996.

Marini RP, Boyce BR (1977). Susceptibility of crown tissues of 'Catskill' strawberry plants to low-temperature injury. J Am Soc Hort Sci 102:515-516.

Mc Kersie BD, Leshem YY (1994). Stress and stress coping in cultivated plants. Kluwer Academic Publishers, DordrechtBoston-London, $256 \mathrm{p}$.

Mittler R, Vanderauwera S, Gollery M, Van Breusegem F (2004). The reactive oxygen gene network in plants. Trends Plant Sci 9:490-498.

Monk LS, Fagerstedt KV, Crawford RMM (1989) Oxygen toxicity and superoxide dismutase as an antioxidant in physiological stress. Plant Physiol 76:456- 459.

Mutlu S, Atıcı Ö, Nalbantoğlu B (2009). Effects of salicylic acid and salinity on apoplastic antioxidant enzymes in two wheat cultivars differing in salt tolerance. Biol Plantarum 53(2):334-338.

Nakano Y, Asada K (1980). Spinach chloroplasts scavenge hydrogen peroxide on illumination. Plant Cell Physiol 21:1295-1307.

Noctor G, Foyer CH (1998). Ascorbate and glutathione: keeping active oxygen under control. Annu Rev Plant Physiol Plant Mol Biol 49:249-279.

Palonen P, Buszard D (1997a). Current state of cold hardiness research on fruit crops. Can J Plant Sci 77:399-420.

Palonen P, Buszard D (1997b). Screening strawberry cultivars for cold hardiness in vitro. Proceedings of Third International Strawberry Symposium. Acta Hort 439(1):217-220.

Palonen P, Lindén L (2002). Winter survival of strawberry as affected by the type of planting material. Proceedings of the Fourth International Strawberry Symposium. Acta Hort 567:329-332. 
122

Paquin R, Bolduc R, Zizka J, Pelletier G, Lechausser P (1989). Frost tolerance, sugar and proline content of strawberry (Fragaria ananassa Duch) (in French with English abstract). Can J Plant Sci 69:945-954.

Passardi F, Penel C, Dunand C (2004). Performing the paradoxical: how plant peroxidases modify the cell wall. Trends Plant Sci 9:534-540.

Patykowski J, Urbanek H (2003). Activity of enzymes related to $\mathrm{H}_{2} \mathrm{O}_{2}$ generation and metabolism in leaf apoplastic fraction of tomato leaves infected with Botrytis cinerea.J Phytopathol 151:153-161.

Rajinder SD, Dhinsa PP, Thorpe TA (1981). Leaf senescense:corralated with increased levels of membrane permeability and lipid peroxidation and decreased levels of superoxide dismutase and catalase. J Exp Bot 32(126):93101.

Rao MV, Paliyath G, Ormrod DP (1996). Ultraviolet-B- and ozone induced biochemical changes in antioxidant enzymes of Arabidopsis thaliana. Plant Physiol 110:125-136.

Reulland E, Vaultier MN, Zachowski A, Hurry V (2009). Cold signalling and cold acclimation in plants. Adv Bot Res 49:35-126.

Rout NP, Shaw BP (2001). Salt tolerance in aquatic macrophytes:possible involvement of the antioxidative enzymes. Plant Sci 160:415-423.

Sakurai N (1998). Dynamism of apoplast. J Plant Res 111:131.

Shinozaki K, Yamaguchi-Shinozaki K (2000). Molecular responses to dehydration and low temperature: differences and cross-talk between two stress signaling pathways. Curr Opin Plant Biol 3:217-223.

Smirnoff N (1995). Antioxidant systems and plant response to the environment, 217-243 p. In: Smirnoff N (Ed.) Environment and plant metabolism: flexibility and acclimation. UK: Bios Scientific Publishers, Oxford.

Suzuki N, Mittler R (2006). Reactive oxygen species and temperature stresses: a delicate balance between signaling and destruction. Physiol Plant 126:45-51.
Taşgın E, Atıcı Ö, Nalbantoğlu B, Popova LP (2006). Effects of salicylic acid and cold treatments on protein levels and on the activities of antioxidant enzymes in the apoplast of winter wheat leaves. Phytochemistry 67:710-715.

Taşgın E, Atıcı Ö, Nalbantoglu B (2003). Effects of salicylic acid and cold on freezing tolerance in winter wheat leaves. Plant Growth Regul 41:231-236.

Thomashow MF, Browse J (1999). Plant Cold Tolerance, 6180 p. In: Shinozaki K, Yamaguchi-Shinozaki K (Eds.). Molecular Responses to Cold, Drought, Heat and Salt Stress in Higher Plants. R.G. Landes Company, Texas.

Thomashow MF (2010). Molecular Basis of Plant Cold Acclimation: Insights Gained from Studying the CBF Cold Response Pathway. Plant Physiol 154:571-577.

Turan Ö, Ekmekçi Y (2011). Activities of photosystem II and antioxidant enzymes in chickpea (Cicer arietinum L.) cultivars exposed to chilling temperatures. Acta Physiol Plant 33:67-78.

Turhan E, Evrenosoğlu Y, Baykul A, Aydoğan Ç (2011). Determination of low temperature tolerance of some strawberry cultivars (In Turkish with English abstract). Proc of 1st National Agriculture Congress and Exposition on behalf of Ali Numan Kıraç with International Participation, 1:891-897.

Turhan E (2012). Seasonal alteration of sugar metabolism in strawberry (Fragaria $\mathrm{x}$ ananassa) plants during coldacclimated and non-acclimated stages. Afr J Biotechnol 11(20):4558-4565.

Xue Y, Peng R, Xiong A, Li X, Zha D, Yao Q (2009). Yeast heatshock protein gene HSP26 enhances freezing tolerance in Arabidopsis. J Plant Physiol 166:844-850.

Vanacker H, Carver TLW, Foyer CH (1998). Pathogen-induced changes in the antioxidant status of the apoplast in barley leaves. Plant Physiol 117:1103-1114.

Zhang Y, Tang H, Luo Y (2008). Variation in antioxidant enzyme activities of two strawberry cultivars with shortterm low temperature stress. World J Agric Sci 4:458-462. 